\title{
The Effects of Agency Costs and Insiders' Shareholdings on Financing Choices
}

\author{
Chia-Ying Liu \\ Department of Business Administration, Asia University, Taiwan \\ Shiu-Chen Huang \\ King Steel Machinery Co., Ltd., Taiwan \\ Shieh-Liang Chen \\ Department of Business Administration, Asia University, Taiwan \\ E-mail: peterchen@asia.edu.tw
}

Received: Feb. 20, 2016 Accepted: March 22, $2016 \quad$ Published: June 1, 2016

doi:10.5296/ajfa.v8i1.9248 URL: http://dx.doi.org/10.5296/ajfa.v8i1.9248

\begin{abstract}
This paper investigates the effects of debt agency cost and equity agency cost of current and prior periods on the financing choices of long-term debts, seasoned equity offering, and private equity financings. It also examines the effects of the shareholdings of insiders on the association between both debt and equity agency costs and the choice of financing methods.

The findings show that both prior and current debt agency costs are positively related to seasoned equity offerings of current period, and both prior and current debt agency costs are positively related to private equity financing of current period regardless of whether the models consider the factor of insiders' shareholdings. As for equity agency cost, the document indicate that both current and prior equity agency costs are negatively related to current seasoned equity offerings, however, only prior equity agency costs are negatively related to current seasoned equity offerings under considering shareholdings of insiders. Moreover, the shareholdings of insiders would affect the positive association between the corporate debt agency cost and seasoned equity offerings and the positive association between the corporate equity agency cost and debt financing.
\end{abstract}

Keywords: Debt agency cost, Equity agency cost, Seasoned equity offering, Long-term debts, Private equity, Insider's shareholdings 


\section{Introduction}

A firm should concern factors when making financing decisions, but the choice of financing methods depends on whether it can maximize the corporate benefits. The act of financing not only enables a firm to obtain sufficient capital, but also maximizes corporate benefits, and facilitates the implementation of follow-up policies. Myers and Majluf (1984) suggested that most firms issue bonds to gain capital, so as to receive more investment opportunities with greater value. However, compared with the investors, the managers of firms have clearer knowledge over the internal operation of firms. In case of information asymmetry, a firm could gain more capital through different financing channels. ${ }^{1}$

According to Jensen and Meekling (1976), the agency cost is attributable to the acts of managers motivated by self-interest in order to pursue personal gains in case of the separation of ownership and operation rights. This is detrimental to the overall corporate benefits, increases the corporate debt and equity agency costs, causes poor corporate operation performance, and results in loss of shareholder value under the separation of ownership and operation rights (Fama and Jensen, 1983b). Both the academia and practitioner concern about how to improve corporate governance. Divergence exists in Taiwan regarding the study of governance structure. By reference to the corporate governance mechanism, this paper discusses the correlation between the agency cost and financing decisions as well as the impact of number of shares held by insiders on the correlation between agency cost and financing decisions.

When a firm is in need of capital, capital can be obtained through issuance of new shares or debt. In case of issuance of new shares, due to increase of external shareholders, surplus is incurred, the book value is diluted, and the agency issues are incurred. Nevertheless, receiving capital through debt elevates the credit risks of firms, and results in increased agency cost to shareholders and creditors. The employment of financial leverage could decide what financing method is to use, which further affects the corporate value. The corporate debt methods are merely debt from financial institutions or issuance of corporate bonds. The reasons for debt from banks and issuance of corporate bonds lie in the characters of industries and tendency to gain trust of banks or bondholders, so financing from banks or bondholders could be gained smoothly. On the other hand, either the financing method of debt or issuance of new shares incurs cost for financing. Since the rate of returns required by debt is lower than that of issuing new shares, the majority of firms believe that debt financing could reduce the total capital cost, which further elevates the corporate value of firms. Comparatively speaking, the debt agency cost is lower.

Another source of capital is private equity financing. Lee and Kocher (2001) pointed out that firms that engage in private equity financing are those of small scale, high growth, financial difficulty and lacking external capital. Moreover, the private equity acts are not easily affected by market mispricing. Due to high interest rates of debt or other factors that incapacitate firms to borrow money from financial institutions, firms would turn to the private equity financing. Cronqvist and Nilsson (2005) argued that firms whose information is not transparent might select private equity due to cost factors.

\footnotetext{
${ }^{1}$ Myers and Majluf (1984) proposed that as the debt risks are lower than increment of cash, under the substantial investment theories, the firms intend to obtain investment opportunities with growth capacity and engage in financing. Therefore, the external financing of firms tend to be financing by debt, while firms need capital injection due to investment opportunities, if they have run out of debt capacity, firms are not likely to issue securities, as the risks are high and such investment opportunities might be abandoned.
} 
The stakeholders are based on a contractual relation. Besides the shareholders and the creditors, there are still issues regarding large and small shareholders, while shareholders and creditors or managers would incur the agency issues for the pursuit of personal gains. From the debt relation view, when a firm has a high leverage, it is more likely to have a conflict for corporate dividend between the creditors and the shareholders (Ahmed et al. 2002). As the investment risks of creditors increase with the long-term debt ratio, the creditors may request for higher returns for the sake of personal interests, which in turn increases the debt cost of firms. From the viewpoints of equity cost, when the equity held by the shareholders of firms is enough to effectively control the decision-making rights of firms, the controlling shareholders may be motivated to continue maintenance of the equity. Consequently, when the shareholdings of controlling shareholders are high, the returns of stock are also high, which further increases the equity cost of firms.

If the conflicts of interests for stakeholders among agency relations are high, the required returns by creditors and shareholders are also higher, which burdens the agents with relatively higher capital cost and increasingly higher derived agency cost. The agency issues are reflected in the equity agency cost and debt agency cost. This paper attempts to understand the agency cost for different financing methods, and the roles played by debt agency cost and equity agency cost in financing decision-making. The proportion of shares held by the insiders imposes impact on the agency cost. Although many studies have explored the corporate governance, agency cost and corporate value, few have focused on how the shareholdings of insiders impact the relationship between agency cost and financing decision-making. This is the motivation of this study.

As there are diversified financial tools, the financing decision-making methods in the financial polices pay more attention to the selection than in the past. The public offering firms issue securities in the market, the equity disperse degree increases along with the issuance extent of equity. Due to market transaction, the stakeholders change frequently. For the purpose of smooth operation, professional managers are recruited to formulate and implement decision-making on behalf of firms. For this reason, while firms intend to engage in financing acts, the decision-making ability and shareholding conditions of managers should be considered, as managers are an important factor that affects whether firms implement various financing decision-making. On the other hand, with regard to capital structure, while in need of capital, firms could gain capital through issuance of new shares or debt. Gaining capital through debt would elevate the credit risks of firms, which results in increase in agency cost to shareholders and creditors. Hence, the balance point must be obtained among various costs, which decides the corporate capital structure, namely, the trade-off theory proposed by Myers (1984).

According to previous empirical results (Hessel and Norman, 1992; Wahal and McConnell, 2000), shareholding by major shareholders and debt policies could effectively reduce agency problems. These tools are interactional with decision-making regarding investment, debt, dividend, and corporate risks and value. When the shares held by the insiders increase, the managers may dedicate to the $\mathrm{R} \& \mathrm{D}$, advertising or HR cost after considering the long-term competitiveness and their wealth, so as to increase the corporate value. The change in shareholdings of managers also affects the correlation of agency cost and corporate financing decision-making.

This paper first discusses whether firms tend to choose seasoned equity offering for financing while the debt agency costs of prior and current periods are high. Second, it discusses whether firms tend to choose private equity method for financing, while the debt agency cost 
of prior and current periods are high. Third, it discusses the whether the shareholdings by the insiders would affect the relationship between the debt agency cost and the seasoned equity offerings financing, and whether the shareholdings of insiders would affect the relationship between the equity agency cost and the debt financing of firms. Lastly, it discusses whether the shareholdings by the insiders would affect the relationship between the agency cost and private equity financing of firms.

The contributions of this study are as follows. Most past studies on financing acts focus on both seasoned equity offerings and debt financings, rarely relating to private equity financing; however, either the market timing theory or precautionary motive theory is related to the private equity. Thus, this paper integrates the agency cost and financing decision-making into the financing method of private equity. Second, according to previous literatures, firms with relatively higher investment opportunities have higher debt agency cost; hence, the debt agency cost is measured by the market to book ratio of equity. According to Singh and Davidson III (2003), and Tsai, Shao and Yang (2008), the equity agency cost is measured by selling and administrative expenses ratio and the total asset turnover. The second contribution of this study is to simultaneously consider the debt and equity agency costs.

The remainder of this paper is organized as follows: Section 2 presents the literature review. Section 3 explains the empirical methodology, including research design, research periods, sampling criteria and variable definitions, and proposing the empirical models. Section 4 summarizes the empirical result, and the conclusions are given in Section 5.

\section{Literature Review and Hypothesis Development}

According to McKnight and Weir (2009), as for the measurement method of agency cost, the debt agency cost is measured by the market ot book ratio of equity. The definition of equity agency cost is limited to the improper control and management (including prerogative consumption) over discretionary expenses and inefficient operation by managers. According to Ang, Cole, and Lin (2000), the selling and administrative expenses ratio and asset turnover are employed to measure the equity agency cost.

John and Senbet (1998) discuss how firms resolve agency problems via control mechanism in terms of capital structure. Besides the equity agency problems, debt agency problems and social agency problems impose impact on the operation performance. Thus, when the impact on corporate performance by agency problem is studied, debt agency problem is an important factor to be considered for agency cost. Berger, Ofek, and Yermack (1997), and John and Senbet (1998) point out that since shareholders assume limited responsibilities, the creditors only receive returns of fixed benefits. As a result of the debt agency problem, creditors transfer the debt agency cost to the shareholders through increase of debt limits, and the managers may be forced to forsake the profitable investment plans due to increase of debt cost, which results in economic inefficiency.

Frank and Goyal (2003) indicate that when firms intend to invest, if the needed capital cannot be supplied internally, firms would engage in external financing acts, which are categorized into issuance of stocks and debts. Marchica and Mura (2010) argue that if the firms have extra debt capacity, it is easier for them to obtain external financing, and the future investment expenditure is significant. In other words, proper debt enables firms to keep sound financial elasticity and the investment returns of firms in the future are greater.

Malmendier, Tate, and Yan (2011) suggest that internal capital is preferred to be used to support the capital demand of the firms as managers may overestimate the future cash flow of 
firms, and believe that the financing cost of external financing particularly equity financing is high, thus overestimating their own capabilities. Moreover, when firms need external financing, they still prefer debt to issuance of equity. In case of debt, managers tend to be conservative over debt financing. Malmendier, Tate, and Yan (2011) find that managers mostly employ risk-free debt or long-term debt for financing. As a result, the debt in the decision-making of the financing referred to in this study means long-term debt.

Equity agency cost affects firms whether to employ the financing method of seasoned equity offerings, and debt agency cost affects whether to finance through debt from banks or issuance of bonds. Therefore, when discussing the agency cost, both equity agency cost and the debt agency cost should be analyzed, so as to have an overall view over the agency problems and issues. For this reason, when discussing the impact of agency cost on debt or equity financing decision-making, this study analyzes the equity agency cost and the debt agency cost simultaneously.

From the views of insufficient investment, Myers (1977) argues that in order to avoid sole enjoyment of investment's returns by creditors, the shareholders of debt firms tend to select sub-optimal investment plans that results in insufficient issues or under-investment, while the creditors would require relatively lower bond price when undertaking bonds in order to protect their own interest, which makes firms confront the debt agency cost of underestimated bond price. Since firms bear these debt agency cost, the capital cost of debt increases and decreases the willingness of debt, for this reason, we expected that there is a negatively association between debt agency cost and debt ratio.

Myers (1984) and Myers and Majluf (1984) propose that the information asymmetry between the managers and the investors may impact the financing acts of firms. The investors render lower share price in case of equity financing by firms, or request higher return, which leads to adverse selection and causes obstruction in financing. Jensen (1986) proposes that the debt of firms could refrain from the over-investment acts of managers, and in case of external financing, the creditors are also liable for supervision on firms, which increases the corporate value.

Cronqvist and Nilsson (2005) indicate that firms whose information is not transparent tend to finance through private equity due to consideration in cost factors and rights of control. When the information asymmetry between firms and investors is high, firms chooses the private equity for financing. Lee and Kocher (2001) argue that the firms engaging in private equity are mostly small in scale, high in growth, difficult in finance, and lacking external capital. Moreover, the financing motivation and features of both private equity firms and public offering firms are not easily vulnerable to the mispricing of market. It can be seen that financing motivation and features of private equity firms and public offering firms have significant disparity. Financing by private equity is the act of private equity firms who have strong demand over external capital. This study deduces that the higher the agency cost of corporate equity and debt is, the more likely the firms tend to select private equity for financing.

Based on the above, this study proposes the following hypotheses:

H1a: When the debt agency cost is high, the firms are more likely to select financing by seasoned equity offerings.

H1b: When the equity agency cost is high, the firms are more likely to select debt financing. 
H1c: When the agency cost is high, the firms are more likely to select private equity for financing.

Jensen and Mecking (1976) point out that when the shareholdings of managers increase, the interests of managers and shareholders are more likely to be consistent, the motivation for prerogative consumption is slim. Thus, when the shareholdings of managers are high, the corporate performance is better. Rosenstein and Wyatt (1997) suggest that when the insiders have professional knowledge of corporate operation, they are more likely to formulate decisions than the externals in a more effective manner. However, the increase of the shareholding of insiders is more likely to hurt the interests of outside shareholders.

Ang, Cole, and Lin (2000) indicate that after the listed firms raise funds in the market, the ownership is decentralized, the shareholdings of managers reduces as well, less capital contribution or low shareholding level may become the issue. The interests of managers that control the rights of management of firms apparently deviate from the corporate interests, or even infringe the interests of small and medium shareholders. Ang, Cole, and Lin (2000) found that when firms are managed by external parties, the agency cost is relatively high. Second, the agency cost of firms and the shareholdings of managers are negatively correlated. When the shares held by the non-managers increase, the agency cost increases as well. Jensen and Meckling (1976) argue that shareholdings of managers and the agency cost are negatively correlated, namely, when the shareholdings of managers is low, their debt agency cost and equity agency cost are higher. This paper discusses whether the shareholding of insiders would affect the correlation between the agency cost and the corporate financing selection.

This study predicts that if the shareholding ratio by insiders is high, even though the equity agency cost is high due to pursuit of personal interests, the equity financing method may be employed; on the contrary, if the shareholding of insiders is high, even though the debt agency cost is high due to pursuit of personal interests, the debt financing method may be employed. Based on the above, this study proposes the following hypotheses:

H2a: Shareholdings of insiders affect the positive correlation between the corporate debt agency cost and the financing choice of seasoned equity offerings.

$\mathrm{H} 2 \mathrm{~b}$ : Shareholdings of insiders affect the positive correlation between the corporate equity agency cost and the financing choice of debts.

H2c: Shareholdings of insiders affect the relationship between the corporate agency cost and the financing choice of private equity.

\section{Research Design}

\subsection{The data}

Our initial data is drawn from the Taiwan Economic Journal (TEJ) database for the 2006-2012 periods. To calculate the turnover of assets, the source data for this variable cover the 2005-2012 period. Our final sample consists of 5,759 firm-year observations. The sample is limited to publicly traded companies listed on the Taiwan Stock Exchange (TSE) and Over-The-Counter (OTC), excluded state-owned enterprise, financial service and insurance companies from the original sample because they have unique operating characteristics and 
are governed by specific regulations. Moreover, we deleted observations without complete financial data or discontinuous data or invalid data.

The electronics industry is the most heavily covered industry, more than half of the total sample. Followed by chemical, biotech and medical care industries and then electronic appliances \& machinery industries, accounted for $6.64 \% 6.45 \%$ of the total samples, respectively.

\subsection{Empirical model}

This study adopts logistic models to examine Hypotheses 1a, 1b, and 1c. For H1a and H1b, we investigate the association between agency costs of lag-one period, seasoned equity offering financing, and debt financing. We employ agency costs of lag-one period to analyze the impact of debt financing in order to avoid the problem of endogeneity. These specifications are as follows:

$$
\begin{aligned}
& \text { SEODebt }_{i t}=a_{0}+a_{1} \text { DAgency }_{i t-1}+a_{2} \text { EAgency }_{i t-1}+a_{3} A S_{i t}+a_{4} R O A_{i t}+e_{i t} \\
& \text { SEODebt }_{i t}=a_{0}+a_{1} \text { DAgency }_{i t-1}+a_{2} \text { OAgency }_{i t-1}+a_{3} A S_{i t}+a_{4} R O A_{i t}+e_{i t}
\end{aligned}
$$

Similarly, H1c examines the relationship between agency costs of lag-one period and private equity financing. To avoid endogeneity, we introduce agency costs of lag-one period to analyze the effects on private equity financing choice. We rely on the following regressions:

$$
\begin{aligned}
& \text { PRIDS }_{i t}=a_{0}+a_{1} \text { DAgency }_{i t-1}+a_{2} \text { EAgency }_{i t-1}+a_{3} A_{i t}+a_{4} R O A_{i t}+e_{i t} \\
& \text { PRIDS }_{i t}=a_{0}+a_{1} \text { DAgency }_{i t-1}+a_{2} \text { OAgency }_{i t-1}+a_{3} A_{i t}+a_{4} R O A_{i t}+e_{i t}
\end{aligned}
$$

where SEODebt: a dummy variable for equity which equal to 1 if firms make seasoned equity offering and 0 if firm raise capital via banking, issuing bonds, or private equity financing. PRIDS: a dummy variable for private equity which equal to 1 if firms use private equity financing and 0 if firm raise capital via banking, issuing bonds, or seasoned equity offering. DebtSEO: a dummy variable for debts which equal to 1 if firms raise capital via banking and issuing bonds and 0 if firms make seasoned equity offering or private equity financing. DAgency: debt agency costs, measured by market-to-book ratio of equity (MB). Firms with higher MB represent higher the growth opportunities, whereas the higher debt agency costs then the lower long-term debt. EAgency: equity agency costs, measured by the sample's operating expense (selling and administrative expenses) ratio minus the median of operating expense ratios of all firms in an industry. OAgency: equity agency costs, measured by the sample's turnover of assets minus the median of turnover of assets of all firms in an industry. AS: the natural log of total assets, controlled for the firm's size. ROA: return on total assets, indicating that firm's profitability and managers use total assets to create profits for their shareholders.

In addition, we also examine the relationship between current period's agency costs, seasoned equity offering, and private equity financing. The models are as follows:

$$
\begin{gathered}
\text { SEODebt }_{i t}=a_{0}+a_{1} \text { DAgency }_{i t}+a_{2} \text { EAgency }_{i t}+a_{3} A S_{i t}+a_{4} \text { ROA }_{i t}+e_{i t} \\
\text { PRIDS }_{i t}=a_{0}+a_{1} \text { DAgency }_{i t}+a_{2} \text { EAgency }_{i t}+a_{3} A S_{i t}+a_{4} R O A_{i t}+e_{i t}
\end{gathered}
$$

As the above model, the measure our proxies for debt agency costs that adopts market to book ratio (MB), measured with the market value of equity divided by the book value of 
equity. Additionally, following Singh and Davidson (2003) and Tsai et al. (2008), our equity agency costs are measured by both turnover of assets and operating expenses ratio.

This study uses the sum of the cumulative shareholdings ratio held by executives, directors and supervisors, and blockholders to measure the shareholdings of insiders. To further test the relationship between shareholdings of insiders and firm's financing choices as well as test the effects of the interaction term between shareholdings of insiders and agency costs on the financing choice. To validate Hypotheses $2 \mathrm{a}$ and $2 \mathrm{~b}$ and control for endogeneity, we adopt prior shareholdings of insiders, prior equity agency costs, and prior debt agency costs to analyze their impact on financing choices. Two regression models are presented in the following:

$$
\begin{aligned}
\text { SEODebt }_{i t}= & a_{0}+a_{1} \text { DAgency }_{i t-1}+a_{2} \text { EAgency }_{i t-1}+a_{3} \text { InsideS }_{i t-1}+a_{4} \text { DAgency }_{i t-1} \text { InsideS }_{i t-1} \\
& +a_{5} \text { EAgency }_{i t-1} \text { InsideS }_{i t-1}+a_{6} A S_{i t}+a_{7} R O A_{i t}+e_{i t}
\end{aligned}
$$

$$
\begin{aligned}
\text { SEODebt }_{i t}= & a_{0}+a_{1} \text { DAgency }_{i t-1}+a_{2} \text { OAgency }_{i t-1}+a_{3} \text { InsideS }_{i t-1}+a_{4} \text { DAgency }_{i t-1} \text { InsideS }_{i t-1} \\
& +a_{5} \text { OAgency }_{i t-1} \text { InsideS }_{i t-1}+a_{6} A S_{i t}+a_{7} R O A_{i t}+e_{i t}
\end{aligned}
$$

We rely on the following model to examine $\mathrm{H} 2 \mathrm{c}$, that shareholdings of insiders affect the relations between agency costs and private equity financing. As mentioned above, to avoid endogeneity problems, we introduce lag-one period's shareholdings of insiders and lag-one period's agency costs to analyze their effects on private equity financing choice. Two specifications are as follows:

$$
\begin{aligned}
\text { PRIDS }_{i t}= & a_{0}+a_{1} \text { DAgency }_{i t-1}+a_{2} \text { EAgency }_{i t-1}+a_{3} \text { InsideS }_{i t-1}+a_{4} \text { DAgency }_{i t-1} \text { Inside }_{i t-1} \\
& +a_{5} \text { EAgency }_{i t-1} \text { InsideS }_{i t-1}+a_{6} A S_{i t}+a_{7} \text { ROA }_{i t}+e_{i t}
\end{aligned}
$$

$$
\begin{aligned}
\text { PRIDS }_{i t}= & a_{0}+a_{1} \text { DAgency }_{i t-1}+a_{2} \text { OAgency }_{i t-1}+a_{3} \text { InsideS }_{i t-1}+a_{4} \text { DAgency }_{i t-1} \text { InsideS }_{i t-1} \\
& +a_{5} \text { OAgency }_{i t-1} \text { InsideS }_{i t-1}+a_{6} A S_{i t}+a_{7} \text { ROA }_{i t}+e_{i t}
\end{aligned}
$$

Moreover, we further explore the relationship between shareholdings of insiders, agency costs and financing choices in the current period. The two research models are presented in the following:

$$
\begin{aligned}
\text { SEODebt }_{i t}= & a_{0}+a_{1} \text { DAgency }_{i t}+a_{2} \text { EAgency }_{i t}+a_{3} \text { InsideS }_{i t}+a_{4} \text { DAgency }_{i t} \text { InsideS }_{i t} \\
& +a_{5} \text { EAgency }_{i t} \text { InsideS }_{i t}+a_{6} A S_{i t}+a_{7} \text { ROA }_{i t}+e_{i t} \\
\text { PRIDS }_{i t}= & a_{0}+a_{1} \text { DAgency }_{i t}+a_{2} \text { EAgency }_{i t}+a_{3} \text { InsideS }_{i t}+a_{4} \text { DAgency }_{i t} \text { InsideS }_{i t} \\
& +a_{5} \text { EAgency }_{i t} \text { InsideS }_{i t}+a_{6} \text { AS }_{i t}+a_{7} \text { ROA }_{i t}+e_{i t}
\end{aligned}
$$

where InsideS: shareholdings of insiders, which is the sum of the cumulative shareholdings ratio held by insiders (executives, directors and supervisors, and blockholders). DAgency*InsideS: the interaction term between debt agency costs and shareholdings of insiders. EAgency*InsideS: the interaction term between equity agency costs and shareholdings of insiders, which equity agency costs is measured by the firm's operating 
expense ratio minus the median of operating expense ratios of all firms in an industry. Oagency*InsideS: the interaction term between equity agency costs and shareholdings of insiders, which equity agency costs is measured by the firm's assets turnover minus the median of assets turnovers of all firms in an industry. The definitions of other variables are as the same as Equation (1).

\subsection{Variable definitions}

\section{Debt agency cost (DAgency)}

Prior literature concerning firms with higher investment opportunities usually have higher debt agency costs, thereby reduces the cost of debt financing. As R\&D expenses and advertising expenses can be viewed as a proxy for firm's investment opportunities, denotes that $R \& D$ expenses and advertising expenses are inversely related to the long-term debt. In this study, we use market-to-book ratio (MB) as a measure of agency costs of debt, calculated with the market value of equity divided by the book value of equity. The companies with higher MB exhibit higher the growth opportunities, have higher agency costs of debt, and then lower long-term debt.

\section{Equity agency cost (OAgency, EAgency)}

Ang, Cole, and Lin (2000) measure agency costs of the firm that use two alternative efficiency ratios: the operating expense ratio, which is operating expense scaled by net sales, and the turnover of assets, which is net sales divided by total assets. The asset turnover is a measure of how effectively the firm's management deploys its assets. Higher turnover of asset is associated with greater efficiency for asset management, indicating that managers can generate higher cash flows and increase sales. In turn, lower turnover of asset indicates that managers invest in less efficiency activities. To control the impact of industry effects, we use OAgency as a proxy for agency costs, measured by the sample firm's asset turnover minus the median of asset turnovers of sample firms in an industry. Moreover, the measurement of equity agency costs (EAgency) is measured by the sample firm's selling and administrative expense (operating expense) ratio minus the median of operating expense ratio of sample firms in an industry. Companies with higher agency cost exhibit greater the volatility of return on assets, higher operating expense ratio, and lower asset turnover ratio.

\section{Seasoned equity offering financing choice $\left(\mathrm{SEODebt}_{\mathrm{it}}\right)$}

We apply logistic regression analysis to assess the company's financing choice, SEODebt ${ }_{i t}$ as measures of making seasoned equity offering. SEODebt $t_{i t}$ is a dummy variable that is equal to one if firms make seasoned equity offering and zero if firms raise the fund via banking, issuing bonds, or private equity financing.

\section{Private equity financing choice $\left(\right.$ PRIDS $\left._{i t}\right)$}

We apply logistic regression analysis to assess the company's financing choices, PRIDS as measures of using private equity. PRIDS is a dummy variable that is equal to one if firms make private equity financing and zero if firm raise the fund via banking, issuing bonds, or seasoned equity offering.

\section{Shareholdings of insiders (InsideS)}

Total shares held by insider of a firm. This study measures insiders is according to Taiwanese Securities and Futures Bureau, Financial Supervisory Commission's brochures, contain executives, directors and supervisors, and blockholders. 


\section{The Results}

\subsection{Descriptive statistics}

The descriptive statistics for each variable in regression models of this study are shown in Table 1. The findings show that the mean of DebtSEO ${ }_{\text {it }}$ is 0.9413 , implying that under lack of funds, the firm prefers to engage in debt financing, rather than in seasoned equity offerings. This is consistent with the traditional financing pecking order theory. The mean of SEODebt ${ }_{i t}$ is 0.2012 , indicating that the company will be less seasoned equity offerings to finance.

The mean of PRIDSit is 0.0803 , which represents the company's financing decisions do not tend to private equity (private placement) but debt or seasoned equity offerings for financing. Cronqvist and Nilsson (2005) find that, no matter what the agency cost financing decisions, the firm with opaque information tend to choose private equity financing due to cost factors. However, Lee and Kocher (2001) find that the firm with private placement will has a smaller firm size, high growth, and better financial position than the firm with seasoned equity offerings.

In addition to stock's market-to-book ratio (MB), the firm's selling and administrative expenses minus the industry's median of selling and administrative expenses, and the firm's turnover of assets minus the industry's median of turnover of assets to measure equity agency cost, we also use the sum of ratios of insider ownership (InsideS $\mathrm{it-1}_{\text {it }}$ ) to measure shareholdings of insiders. The maximum and minimum values of InsideS $_{\text {it- } 1}$ are 99.9500 and 7.8000 , respectively, and with a standard deviation of 17.0849, show that corporate insiders shareholding ratios Inside $S_{\text {it- } 1}$ has a great difference among the sample firms. The possible reason of its mean of 44.0689 is that most of companies are family or group type in Taiwan.

Moreover, the untabulated results of correlation analysis show that correlation coefficients at all between two variables are less than 0.65 , implying that there is no multicollinearity among these variables.

Table 1. Descriptive statistics

\begin{tabular}{lrrrr}
\hline & \multicolumn{1}{c}{ Mean } & Std. Dev. & Minimum & \multicolumn{1}{c}{ Maximum } \\
\hline DAgency & 1.5688 & 2.6768 & 0.0700 & 119.6300 \\
EAgency & 0.1171 & 0.6078 & -1.1500 & 6.5600 \\
OAgency & 3.6663 & 25.3511 & -29.8800 & 762.1200 \\
InsideS & 44.0689 & 17.0849 & 7.8000 & 99.9500 \\
AS & 6.7771 & 0.6495 & 5.0330 & 9.3106 \\
ROA & 6.4258 & 8.3334 & -71.9400 & 51.5600 \\
SEODebt & 0.2012 & 0.4009 & 0.0000 & 1.0000 \\
PRIDS & 0.0803 & 0.2717 & 0.0000 & 1.0000 \\
\hline
\end{tabular}

Number of total observations is 5319 .

Variables Definition:

SEODebt is an equity dummy variable, which sets to 1 if the firm chooses seasoned equity offering financing and set to 0 if the firm chooses bank debt, issuing bond, or issuing private equity financings. PRIDS is a private equity dummy variable, which sets to 1 if the firm chooses private equity and set to 0 if the firm chooses bank debt, issuing bond, and seasoned equity offering financings. DAgency is the debt agency cost, which is measured by market to book ratio of equity. EAgency is the equity agency cost, which is measured by the firm's selling and administrative expenses ratio minus the industry median of selling and administrative expenses ratios of all firms in an industry. OAgency is is the equity agency cost, which is measured by the firm's turnover of assets minus the industry median of turnovers of assets of all 
firms in an industry. InsideS is the shareholdings of insiders, which is the sum of managers' shareholdings, directors and supervisors' shareholdings, and blockholders' shareholdings. AS is the nature log of total assets, which controls firm size. ROA is return of assets, which represents the operation performance of a firm.

\subsection{Prior agency cost and seasoned equity offerings}

Model 1 of Table 2 use Logistic regression to analyze the association between previous period's agency costs and seasoned equity offerings, which DAgencyit-1 proxies for the debt agency costs and is measured by equity's market to book ratio. The findings show that DAgency $_{\text {it- } 1}$ is significantly positively related to seasoned equity offerings dummy variable, implying that the firm with higher previous period's debt agency cost, it tends to choose seasoned equity offering in current period. The empirical results are consistent with our expectations that agency costs are endogenous, that is, the current period's financing decisions is affect by the prior period's debt agency cost. A higher MB means the company has higher growth opportunity, and its debt agency cost is higher, so that the company's long-term debt is lower. The empirical result supports Hypothesis 1a. As Kim and Weisbach (2008), a higher MB company is more likely to choose equity financing than a lower MB company.

On the other hand, Mode 1 in Table 2 uses EAgency it-1 $_{1}$ represents the previous period's equity agency cost, which is measured by the previous period's selling and administrative expenses minus the industry's median of selling and administrative expenses. The findings show that the period's equity agent cost is significantly negatively correlated to seasoned equity offerings, indicating that the sample companies' previous period's equity agency costs are higher, their possibilities of engaging in seasoned equity offerings are lower. When higher equity agency costs, operating expense ratio is higher. The empirical results support the hypothesis inference $1 \mathrm{~b}$, and agency costs have are endogenous as expectations, that is, when the previous period's equity agency cost of the company is higher, the company will tend to choose debt financing in current period.

Model 2 in Table 2 uses OAgency ${ }_{\text {it- } 1}$ measure the company's equity agency cost, which is measured by previous period's turnover of assets minus the industry's median of turnover of assets. The findings show that the company's previous period's debt agency cost is higher, the more inclined to choose seasoned equity offerings financing in the current period. Therefore, it is consistent with the results those in the model 1 of Table 2, and empirical results fit for the agency cost of this study is expected to have endogenous, that the current period's financing decisions is affect by the previous period's debt agency cost.

On the other hand, turnover of asset is used to measure efficiency of a firm. If the turnover rate is higher, indicating that managers have better capabilities of asset management, allows assets to generate higher cash flows and sales volume, therefore the lower agency cost of equity. The findings of Model 2 show that the previous period's equity agency cost OAgency $_{\text {it- } 1}$ is positively correlated with the seasoned equity offerings. This means that the higher equity agency costs (the lower turnover of assets), the company is more likely to choose debt financing. Our results are consistent with Myers and Majluf (1984), and the empirical results support the hypothesis $1 \mathrm{~b}$, that the company's equity agency costs is higher, would tend to choose the debt financing. 
Table 2. Prior agency cost and seasoned equity offering choice

\begin{tabular}{|c|c|c|c|c|}
\hline \multicolumn{5}{|c|}{$\begin{array}{l}\text { SEODebt }_{i t}=a_{0}+a_{1} \text { DAgency }_{i t-1}+a_{2} \text { EAgency }_{i t-1}+a_{3} A S_{i t}+a_{4} R O A_{i t}+e_{i t} \\
\text { SEODebt }_{i t}=a_{0}+a_{1} \text { DAgency }_{i t-1}+a_{2} \text { OAgency }_{i t-1}+a_{3} A S_{i t}+a_{4} R O A_{i t}+e_{i t}\end{array}$} \\
\hline SEODebt & Model 1 & $\left(c y_{i t-1}\right)$ & Model 2 & ency $\left._{\text {it-1 }}\right)$ \\
\hline variable & Coef. & $\begin{array}{c}\text { z value } \\
(\mathrm{P}>|\mathrm{z}|)\end{array}$ & Coef. & $\begin{array}{l}\text { z value } \\
\text { ( } p \text { value) }\end{array}$ \\
\hline DAgency $_{i t-1}$ & 0.2578 & $\begin{array}{c}9.1900 \\
(0.0000)\end{array}$ & 0.2414 & $\begin{array}{c}8.7300 \\
(0.0000)\end{array}$ \\
\hline EAgency $_{\text {it-1 }}$ & -0.1763 & $\begin{array}{l}-2.8500 \\
(0.0040)\end{array}$ & & \\
\hline OAgency $_{\text {it-1 }}$ & & & 0.0085 & $\begin{array}{c}4.1700 \\
(0.0000)\end{array}$ \\
\hline AS & -0.1816 & $\begin{array}{l}-3.1700 \\
(0.0010)\end{array}$ & -0.1285 & $\begin{array}{l}-2.2100 \\
(0.0270)\end{array}$ \\
\hline ROA & -0.0337 & $\begin{array}{l}-7.8300 \\
(0.0000)\end{array}$ & -0.0314 & $\begin{array}{l}-7.2700 \\
(0.0000)\end{array}$ \\
\hline Cons. & -0.3454 & $\begin{array}{l}-0.8900 \\
(0.3720)\end{array}$ & -0.7442 & $\begin{array}{l}-1.8800 \\
(0.0600)\end{array}$ \\
\hline Number of obs. & 5319 & & 5319 & \\
\hline LR chi2(5) & 181.06 & & 199.04 & \\
\hline Prob $>$ chi 2 & 0.0000 & & 0.0000 & \\
\hline Pseudo $\mathrm{R}^{2}$ & 0.0339 & & 0.0373 & \\
\hline
\end{tabular}

Variables Definition:

SEODebt is an equity dummy variable, which sets to 1 if the firm chooses seasoned equity offering financing and set to 0 if the firm chooses bank debt, issuing bond, or issuing private equity financings. DAgency is the debt agency cost, which is measured by market to book ratio of equity. EAgency is the equity agency cost, which is measured by the firm's selling and administrative expenses ratio minus the industry median of selling and administrative expenses ratios of all firms in an industry. OAgency is the equity agency cost, which is measured by the firm's turnover of assets minus the industry median of turnovers of assets of all firms in an industry. AS is the nature $\log$ of total assets, which controls firm size. ROA is return of assets, which represents the operation performance of a firm.

\subsection{Prior agency cost and private equity}

Model 1 in Table 3 uses DAgency ${ }_{i t-1}$ to measure the debt agency costs, which is equity's market to book ratio. The findings show that $\mathrm{DAgency}_{\mathrm{it}-1}$ is significantly positively correlated with private equity financing dummy variable $\left(\mathrm{PRIDS}_{\mathrm{it}}\right)$, implying that the prior period's debt agency costs are higher, the company tends to choose private equity financing in current period, that is, the prior period's growth opportunity is higher (debt agency costs is higher), the company is more likely to choose private equity, and its long-term debt is lower. The empirical result is consistent with our expectation, debt agency costs have endogenous, that the current financing decision is influenced by the previous agency cost of debt. The empirical result supports Hypothesis 1c. 


\section{Macrothink}

The model 1 in Table 3 show, the company's previous equity agency cost (EAgency it-1) is negatively related to private equity financing (PRIDS $\mathrm{it}_{\mathrm{it}}$ ). This means that when the company's ratio of selling and administrative expenses is higher, its equity agency cost is higher, and then the company is unlikely to use private equity financing. This result supports the hypothesis 1c. At the same time, the empirical results are also consistent with expectations, which the current private equity financing decision is affected by the previous period's equity agency cost.

The Model 2 of Table 3 use DAgency ${ }_{i t-1}$ to measure the debt agency cost. Model 2 uses Logistic regression to explore the association between previous period's agency costs and the private equity. The empirical results show, prior period's debt agency costs DAgency ${ }_{i t-1}$ is positively and significantly related to private equity financing in current period.

In addition, higher turnover of assets indicates asset management capabilities of managers are higher, and then they can create more cash flows and sales, so the equity agency cost is lower. The results of model 2 in Table 3 show that the previous period's equity agency cost OAgency $_{\text {it- } 1}$ is positively correlated with private equity financing, implying that the higher of the previous cash flows and sales of company, its equity agency costs is lower, so that manager is more likely to choose private equity to finance. In contrast, when the manager invests in inefficient productivity, company's equity agency cost is higher and it does not tend to choose private equity. The empirical result supports Hypothesis 1c. 
Table 3. Prior agency cost and private equity choice

\begin{tabular}{|c|c|c|c|c|}
\hline \multicolumn{5}{|c|}{$\begin{array}{c}\text { PRIDS }_{i t}=a_{0}+a_{1} \text { DAgency }_{i t-1}+a_{2} \text { EAgency }_{i t-1}+a_{3} A S_{i t}+a_{4} R O A_{i t}+e_{i t} \\
\text { PRIDS }_{i t}=a_{0}+a_{1} \text { DAgency }_{i t-1}+a_{2} \text { OAgency }_{i t-1}+a_{3} A S_{i t}+a_{4} R O A_{i t}+e_{i t}\end{array}$} \\
\hline PRIDS & \multicolumn{2}{|c|}{ Model 1 (EAgency $\left.{ }_{\mathrm{it}-1}\right)$} & \multicolumn{2}{|c|}{ Model 2 (OAgency $\left.{ }_{\mathrm{it}-1}\right)$} \\
\hline variable & Coef. & $\begin{array}{c}\mathrm{z} \text { value } \\
(\mathrm{P}>|\mathrm{z}|)\end{array}$ & Coef. & $\begin{array}{c}\mathrm{z} \text { value } \\
\text { ( } \mathrm{p} \text { value) }\end{array}$ \\
\hline DAgency $_{\text {it-1 }}$ & 0.1188 & $\begin{array}{c}3.0800 \\
(0.0020)\end{array}$ & 0.0854 & $\begin{array}{c}2.2800 \\
(0.0230)\end{array}$ \\
\hline EAgency $_{i t-1}$ & -0.7074 & $\begin{array}{l}-5.8400 \\
(0.0000)\end{array}$ & & \\
\hline OAgency $_{\mathrm{it}-1}$ & & & 0.0086 & $\begin{array}{c}3.6500 \\
(0.0000)\end{array}$ \\
\hline AS & -0.5871 & $\begin{array}{l}-5.9100 \\
(0.0000)\end{array}$ & -0.5204 & $\begin{array}{l}-5.1600 \\
(0.0000)\end{array}$ \\
\hline ROA & -0.0887 & $\begin{array}{r}-13.6700 \\
(0.0000)\end{array}$ & -0.0879 & $\begin{array}{r}-13.5400 \\
(0.0000)\end{array}$ \\
\hline Cons. & 1.6273 & $\begin{array}{c}2.4600 \\
(0.0140)\end{array}$ & 1.1681 & $\begin{array}{c}1.7400 \\
(0.0820)\end{array}$ \\
\hline Number of obs. & 5319 & & 5319 & \\
\hline LR chi2(5) & 445.57 & & 425.91 & \\
\hline Prob $>$ chi 2 & 0.0000 & & 0.0000 & \\
\hline Pseudo $\mathrm{R}^{2}$ & 0.1499 & & 0.1433 & \\
\hline
\end{tabular}

Variables Definition:

PRIDS is a private equity dummy variable, which sets to 1 if the firm chooses private equity and set to 0 if the firm chooses bank debt, issuing bond, and seasoned equity offering financings. DAgency is the debt agency cost, which is measured by market to book ratio of equity. EAgency is the equity agency cost, which is measured by the firm's selling and administrative expenses ratio minus the industry median of selling and administrative expenses ratios of all firms in an industry. OAgency is the equity agency cost, which is measured by the firm's turnover of assets minus the industry median of turnovers of assets of all firms in an industry. AS is the nature log of total assets, which controls firm size. ROA is return of assets, which represents the operation performance of a firm.

\subsection{Current period's agency cost, seasoned equity offerings, and private equity}

Model 1 in Table 4 uses DAgency it to measure debt agency costs (market to book ratio). The findings show that DAgency ${ }_{i t}$ and seasoned equity offerings dummy variable (SEODebtit) have significantly and positively correlation, current debt agency cost is higher, the company tends to choose seasoned equity offerings. The empirical result supports Hypothesis 1a. Overall, from the results of Tables 2 and 4, whether the previous or the current periods' debt agent costs are positively correlated with the choice of seasoned equity offerings in current period. 
Model 1 of Table 4 uses EAgency ${ }_{\text {it }}$ show the company's current equity agency costs, which is the firm's current period's selling and administrative expenses minus industry median of selling and administrative expenses. When the equity agency costs higher, the larger the ratio of operating expenses is. The findings show that the current period's equity agency costs and the financing choice of seasoned equity offerings is significantly negatively correlation, means that the higher equity agency cost of current period, the company is unlikely to choose seasoned equity offerings. The empirical result supports Hypothesis 1b. Overall, from the results of Tables 2 and 4, either the previous period or the current equity agency costs are negatively related to current seasoned equity offerings.

In addition, Model 2 in Table 4 examines the association between agency costs in the current period and the private equity financing. The findings show that private equity financing is positively related to DAgency ${ }_{\text {it }}$ dummy variable (PRIDSit), showing a higher current debt agency costs, the company tend to conduct private equity financing. The empirical result supports Hypothesis 1c. Overall, both previous period and current period debt agency costs are positively correlated with the current period's private equity financing.

Table 4 also shows that equity agency cost EAgency ${ }_{i t}$ is negatively related to private equity financing $\left(\right.$ PRIDS $_{\mathrm{it}}$ ). This means that when ratio of selling and administrative expenses is higher, equity agency cost is higher, so the companies do not tend to use private equity financing. The empirical result supports Hypothesis 1c. Integrated mentioned above, both previous or current periods' equity agency costs are negatively correlated with the current period's private equity financing, so that equity agency cost is higher, the company does not tend to be more interest in fund-raising of equity.

Table 4. Current agency cost, seasoned equity offering and private equity choices

\begin{tabular}{|c|c|c|c|c|}
\hline \multicolumn{5}{|c|}{$\begin{array}{l}\text { SEODebt }_{i t}=a_{0}+a_{1} \text { DAgency }_{i t}+a_{2} \text { EAgency }_{i t}+a_{3} A S_{i t}+a_{4} R O A_{i t}+e_{i t} \\
\text { PRIDS }_{i t}=a_{0}+a_{1} \text { DAgency }_{i t}+a_{2} \text { EAgency }_{i t}+a_{3} A S_{i t}+a_{4} R O A_{i t}+e_{i t}\end{array}$} \\
\hline & $\begin{array}{r}\text { Model } 1 \text { (inc } \\
\text { SI }\end{array}$ & $\begin{array}{l}\text { ent variable: } \\
\text { t) }\end{array}$ & Model 2 (inc & ent variable: \\
\hline variable & Coef. & $\begin{array}{l}\text { zvalue } \\
(\mathrm{P}>|\mathrm{z}|)\end{array}$ & Coef. & $\begin{array}{l}\mathrm{z} \text { value } \\
\text { ( } \mathrm{p} \text { value) }\end{array}$ \\
\hline DAgency $_{i t}$ & 0.2344 & $\begin{array}{c}8.0100 \\
(0.0000)\end{array}$ & 0.1537 & $\begin{array}{c}4.2000 \\
(0.0000)\end{array}$ \\
\hline EAgency $_{i t}$ & -0.1275 & $\begin{array}{l}-2.0900 \\
(0.0370)\end{array}$ & -0.5477 & $\begin{array}{l}-4.7500 \\
(0.0000)\end{array}$ \\
\hline AS & -0.1911 & $\begin{array}{l}-3.3300 \\
(0.0010)\end{array}$ & -0.6103 & $\begin{array}{l}-6.1000 \\
(0.0000)\end{array}$ \\
\hline ROA & -0.0287 & $\begin{array}{l}-6.6000 \\
(0.0000)\end{array}$ & -0.0829 & $\begin{array}{l}-12.8800 \\
(0.0000)\end{array}$ \\
\hline Cons. & -0.2671 & $\begin{array}{l}-0.6900 \\
(0.4930)\end{array}$ & 1.7119 & $\begin{array}{c}2.5900 \\
(0.0100)\end{array}$ \\
\hline $\begin{array}{l}\text { Number of obs. } \\
\text { LR chi2(5) } \\
\text { Prob }>\text { chi2 } \\
\text { Pseudo } \text { R }^{2}\end{array}$ & $\begin{array}{c}5319 \\
159.11 \\
0.0000 \\
0.0298\end{array}$ & & $\begin{array}{c}5319 \\
430.33 \\
0.0000 \\
0.1447\end{array}$ & \\
\hline
\end{tabular}

Variables Definition:

SEODebt is an equity dummy variable, which sets to 1 if the firm chooses seasoned equity offering financing and set to 0 if the firm chooses bank debt, issuing bond, or issuing private 
equity financings. PRIDS is a private equity dummy variable, which sets to 1 if the firm chooses private equity and set to 0 if the firm chooses bank debt, issuing bond, and seasoned equity offering financings. DAgency is the debt agency cost, which is measured by market to book ratio of equity. EAgency is the equity agency cost, which is measured by the firm's selling and administrative expenses ratio minus the industry median of selling and administrative expenses ratios of all firms in an industry. AS is the nature log of total assets, which controls firm size. ROA is return of assets, which represents the operation performance of a firm.

\subsection{Shareholdings of insiders, prior agency cost, and seasoned equity offerings}

Model 1 in Table 5 examines the effect of insiders' shareholdings on the relationship between prior agency cost and seasoned equity offerings. The finding show that under considering shareholdings of insiders, the firm with higher prior debt agency cost DAgencyit-1 tends to engage in seasoned equity offerings financing, and this result is consistent with our expectation. The higher MB implies the higher growth opportunity of a firm, so that the firm has higher agency cost and lower debt financing. Our result supports Hypothesis H1a.

In Model 1 of Table 5, we also adopt EAgency ${ }_{\text {it- } 1}$ to measure prior equity agency cost. The finding show that under considering shareholdings of insiders, prior equity agency cost of a firm is negatively related to seasoned equity offerings financing, implying that the firm with higher prior equity agency cost does not tend to engage in seasoned equity offerings rather debt financing, so the result is consistent with our expectation and supports Hypothesis $1 \mathrm{~b}$.

However, the result in Model 1 of Table 5 shows that the interaction term between insiders' shareholdings and prior debt agency cost is unrelated to current seasoned equity offering financing. This result implies that when higher insiders' shareholdings, the firm with higher debt agency cost does not has higher possibility of engaging in seasoned equity offerings, which supports hypothesis $\mathrm{H} 2 \mathrm{a}$. The possible reason is that most of large firms are family or group types in Taiwan. Moreover, the interaction term between insiders' shareholdings and prior equity agency cost EAgency ${ }_{i t-1}$ is positively related to current seasoned equity offering financing, which supports hypothesis $\mathrm{H} 2 \mathrm{~b}$.

From Model 2 of Table 5, we find that under considering shareholdings of insiders, the firm with higher prior debt agency cost DAgency ${ }_{i t-1}$ tends to engage in seasoned equity offerings financing, and this result supports Hypothesis H1a. Moreover, the turnover of assets implies assets utilization, the firm with higher turnover of assets has lower equity agency cost OAgency $_{\text {it-1 }}$. The result shows that OAgency it-1 $_{1}$ is unrelated to seasoned equity offerings, so that our result does not support Hypothesis H1b.

The result in Model 2 of Table 5 shows that the interaction term between insiders' shareholdings and prior debt agency cost is also unrelated to current seasoned equity offering financing. This result also supports hypothesis H2a. The possible reason is that most of large firms are family or group types in Taiwan. Moreover, the interaction term between insiders' shareholdings and prior equity agency cost OAgency $_{\text {it-1 }}$ is unrelated to current seasoned equity offering financing, which supports hypothesis $\mathrm{H} 2 \mathrm{~b}$. 
Table 5. Insiders' shareholdings, prior agency cost and seasoned equity offering choice

\begin{tabular}{|c|c|c|c|c|}
\hline \multicolumn{5}{|c|}{$\begin{aligned} \text { SEODebt }_{i t}= & a_{0}+a_{1} \text { DAgency }_{i t-1}+a_{2} \text { EAgency }_{i t-1}+a_{3} \text { InsideS }_{i t-1}+a_{4} \text { DAgency }_{i t-1} \text { InsideS }_{i t-1} \\
& +a_{5} \text { EAgency }_{i t-1} \text { InsideS }_{i t-1}+a_{6} A S_{i t}+a_{7} \text { ROA }_{i t}+e_{i t} \\
\text { SEODebt }_{i t}= & a_{0}+a_{1} \text { DAgency }_{i t-1}+a_{2} \text { OAgency }_{i t-1}+a_{3} \text { InsideS }_{i t-1}+a_{4} \text { DAgency }_{i t-1} \text { InsideS }_{i t-1} \\
& +a_{5} \text { OAgency }_{i t-1} \text { InsideS }_{i t-1}+a_{6} \text { AS }_{i t}+a_{7} \text { ROA }_{i t}+e_{i t}\end{aligned}$} \\
\hline SEODebt & \multicolumn{2}{|c|}{ Model 1 (EAgency it-1) } & \multicolumn{2}{|c|}{ Model 2 (OAgency $\left.{ }_{\text {it-1 }}\right)$} \\
\hline variable & Coef. & $\begin{array}{c}\mathrm{z} \text { value } \\
(\mathrm{P}>|\mathrm{z}|)\end{array}$ & Coef. & $\begin{array}{c}\mathrm{z} \text { value } \\
\text { ( } \mathrm{p} \text { value) }\end{array}$ \\
\hline DAgency $_{\text {it- } 1}$ & 0.2983 & $\begin{array}{c}3.6300 \\
(0.0000)\end{array}$ & 0.2457 & $\begin{array}{c}3.0200 \\
(0.0020)\end{array}$ \\
\hline EAgency $_{\text {it- } 1}$ & -0.5346 & $\begin{array}{l}-3.2300 \\
(0.0010)\end{array}$ & & \\
\hline OAgency $_{\text {it }-1}$ & & & 0.0089 & $\begin{array}{c}1.6000 \\
(0.1100)\end{array}$ \\
\hline InsideS $_{\text {it-1 }}$ & 0.0038 & $\begin{array}{c}1.2000 \\
(0.2310)\end{array}$ & 0.0033 & $\begin{array}{c}1.0300 \\
(0.3030)\end{array}$ \\
\hline DAgency $_{\text {it }-1}$ Inside $_{\text {it-1 }}$ & -0.0009 & $\begin{array}{l}-0.6000 \\
(0.5490)\end{array}$ & -0.0002 & $\begin{array}{l}-0.1200 \\
(0.9030)\end{array}$ \\
\hline EAgency $_{\text {it-1 }}$ InsideS $_{\text {it-1 }}$ & 0.0083 & $\begin{array}{c}2.4000 \\
(0.0160)\end{array}$ & & \\
\hline OAgency $_{\text {it-1 }}$ Inside $S_{\text {it-1 }}$ & & & -0.0000 & $\begin{array}{l}-0.0900 \\
(0.9260)\end{array}$ \\
\hline AS & -0.1574 & $\begin{array}{l}-2.7000 \\
(0.0070)\end{array}$ & -0.1138 & $\begin{array}{l}-1.9300 \\
(0.0540)\end{array}$ \\
\hline ROA & -0.0351 & $\begin{array}{l}-8.0600 \\
(0.0000)\end{array}$ & -0.0321 & $\begin{array}{l}-7.3600 \\
(0.0000)\end{array}$ \\
\hline Cons. & -0.6723 & $\begin{array}{l}-1.5400 \\
(0.1250)\end{array}$ & -0.9822 & $\begin{array}{l}-2.2100 \\
(0.0270)\end{array}$ \\
\hline $\begin{array}{c}\text { Number of obs. } \\
\text { LR chi2(5) } \\
\text { Prob > chi2 } \\
\text { Pseudo } R^{2}\end{array}$ & $\begin{array}{c}5319 \\
188.74 \\
0.0000 \\
0.0353\end{array}$ & & $\begin{array}{c}5319 \\
201.12 \\
0.0000 \\
0.0377\end{array}$ & \\
\hline
\end{tabular}

Variables Definition:

SEODebt is an equity dummy variable, which sets to 1 if the firm chooses seasoned equity offering financing and set to 0 if the firm chooses bank debt, issuing bond, or issuing private equity financings. DAgency is the debt agency cost, which is measured by market to book ratio of equity. EAgency is the equity agency cost, which is measured by the firm's selling and administrative expenses ratio minus the industry median of selling and administrative expenses ratios of all firms in an industry. OAgency is is the equity agency cost, which is measured by the firm's turnover of assets minus the industry median of turnovers of assets of all firms in an industry. InsideS is the shareholdings of insiders, which is the sum of managers' shareholdings, directors and supervisors' shareholdings, and blockholders' shareholdings. AS is the nature log of total assets, which controls firm size. ROA is return of assets, which represents the operation performance of a firm. 


\section{Al Macrothink}

4.6 Shareholdings of insiders, prior agency cost, and private equity financing

Model 1 in Table 6 examines the effect of insiders' shareholdings on the relationship between prior agency cost and private equity financing. The finding show that under considering shareholdings of insiders, the firm with higher prior debt agency cost DAgencyit-1 tends to engage in private equity financing, and this result is consistent with our expectation and supports Hypothesis H1c.

In Model 1 of Table 6, we also adopt EAgency ${ }_{i t-1}$ to measure prior equity agency cost. The finding show that under considering shareholdings of insiders, prior equity agency cost of a firm is negatively related to private equity financing, implying that the firm with higher prior equity agency cost does not tend to engage in private equity financing, so the result supports Hypothesis 1c.

However, the result in Model 1 of Table 6 shows that the interaction term between insiders' shareholdings and prior debt agency cost is unrelated to current private equity financing, which supports hypothesis H2c. The possible reason is that most of large firms are family or group types in Taiwan. Moreover, the interaction term between insiders' shareholdings and prior equity agency cost EAgency $\mathrm{it}_{\mathrm{it}}$ is unrelated to current private equity financing, which supports hypothesis $\mathrm{H} 2 \mathrm{c}$.

From Model 2 of Table 6, we find that under considering shareholdings of insiders, the prior debt agency cost DAgency it- $1_{1}$ is unrelated to private equity financing, and this result does not support Hypothesis H1c. Moreover, when using turnover of assets to measure prior equity agency cost $\mathrm{OAgency}_{\mathrm{it}-1}$. The result shows that prior equity agency cost is unrelated to private equity financing, so that the result also does not support Hypothesis H1c.

The result in Model 2 of Table 6 shows that the interaction term between prior period's insiders' shareholdings and prior period's debt agency cost is unrelated to current period's private equity financing. This result still does not support hypothesis H2c. Moreover, the interaction term between prior period's insiders' shareholdings and prior period's equity agency cost OAgency $_{i t-1}$ is unrelated to current period's private equity financing, which still does not supports hypothesis H2c. 
Table 6. Insiders' shareholdings, prior agency cost and private equity choice

\begin{tabular}{|c|c|c|c|c|}
\hline \multicolumn{5}{|c|}{$\begin{aligned} \text { PRIDS }_{i t}= & a_{0}+a_{1} \text { DAgency }_{i t-1}+a_{2} \text { EAgency }_{i t-1}+a_{3} \text { InsideS }_{i t-1}+a_{4} \text { DAgency }_{i t-1} \text { InsideS }_{i t-1} \\
& +a_{5} \text { EAgency }_{i t-1} \text { InsideS }_{i t-1}+a_{6} A S_{i t}+a_{7} \text { ROA }_{i t}+e_{i t} \\
\text { PRIDS }_{i t}= & a_{0}+a_{1} \text { DAgency }_{i t-1}+a_{2} \text { OAgency }_{i t-1}+a_{3} \text { InsideS }_{i t-1}+a_{4} \text { DAgency }_{i t-1} \text { InsideS }_{i t-1} \\
& +a_{5} \text { OAgency }_{i t-1} \text { InsideS }_{i t-1}+a_{6} A S_{i t}+a_{7} \text { ROA }_{i t}+e_{i t}\end{aligned}$} \\
\hline PRIDS & Model 1 & sency it-1 $\left._{1}\right)$ & Model & gency $\left._{\text {it-1 }}\right)$ \\
\hline variables & Coef. & $\begin{array}{c}\text { z value } \\
(\mathrm{P}>|\mathrm{z}|)\end{array}$ & Coef. & $\begin{array}{l}\text { z value } \\
\text { (p value) }\end{array}$ \\
\hline DAgencyit-1 & 0.2037 & $\begin{array}{c}1.6300 \\
(0.1040)\end{array}$ & 0.1137 & $\begin{array}{c}0.9500 \\
(0.3410)\end{array}$ \\
\hline EAgency $_{\text {it- } 1}$ & -1.0971 & $\begin{array}{l}-3.4000 \\
(0.0010)\end{array}$ & & \\
\hline OAgency $_{\text {it-1 }}$ & & & 0.0095 & $\begin{array}{c}1.4600 \\
(0.1460)\end{array}$ \\
\hline InsideS $_{\text {it-1 }}$ & -0.0013 & $\begin{array}{l}-0.2600 \\
(0.7910)\end{array}$ & -0.0036 & $\begin{array}{l}-0.7700 \\
(0.4400)\end{array}$ \\
\hline DAgency $_{\text {it- } 1} \times$ InsideS $_{\text {it- } 1}$ & -0.0016 & $\begin{array}{l}-0.6800 \\
(0.4950)\end{array}$ & -0.0005 & $\begin{array}{l}-0.2100 \\
(0.8340)\end{array}$ \\
\hline EAgency $_{\mathrm{it}-1} \times$ InsideS $_{\text {it- } 1}$ & 0.0091 & $\begin{array}{c}1.3200 \\
(0.1860)\end{array}$ & & \\
\hline OAgency $_{\text {it- } 1} \times$ InsideS $_{\text {it }-1}$ & & & -0.0000 & $\begin{array}{l}-0.1300 \\
(0.8950)\end{array}$ \\
\hline AS & -0.6024 & $\begin{array}{l}-5.9000 \\
(0.0000)\end{array}$ & -0.5454 & $\begin{array}{l}-5.2600 \\
(0.0000)\end{array}$ \\
\hline ROA & -0.6886 & $\begin{array}{r}-13.4600 \\
(0.0000)\end{array}$ & -0.0867 & $\begin{array}{r}-13.2200 \\
(0.0000)\end{array}$ \\
\hline Cons. & 1.7594 & $\begin{array}{c}2.3700 \\
(0.0180) \\
\end{array}$ & 1.4758 & $\begin{array}{c}1.9600 \\
(0.0500)\end{array}$ \\
\hline $\begin{array}{l}\text { Number of obs. } \\
\text { LR chi2(5) } \\
\text { Prob }>\text { chi2 } \\
\text { Pseudo } \mathrm{R}^{2}\end{array}$ & $\begin{array}{c}5319 \\
449.27 \\
0.0000 \\
0.1511\end{array}$ & & $\begin{array}{c}5319 \\
427.74 \\
0.0000 \\
0.1439\end{array}$ & \\
\hline
\end{tabular}

Variables Definition: PRIDS is a private equity dummy variable, which sets to 1 if the firm chooses private equity and set to 0 if the firm chooses bank debt, issuing bond, and seasoned equity offering financings. DAgency is the debt agency cost, which is measured by market to book ratio of equity. EAgency is the equity agency cost, which is measured by the firm's selling and administrative expenses ratio minus the industry median of selling and administrative expenses ratios of all firms in an industry. OAgency is is the equity agency cost, which is measured by the firm's turnover of assets minus the industry median of turnovers of assets of all firms in an industry. InsideS is the shareholdings of insiders, which is the sum of managers' shareholdings, directors and supervisors' shareholdings, and blockholders' shareholdings. AS is the nature log of total assets, which controls firm size. ROA is return of assets, which represents the operation performance of a firm. 
4.7 Shareholdings of insiders, current agency cost and seasoned equity offerings

Model 1 in Table 7 examines the effect of insiders' shareholdings on the relationship between current period's agency cost and seasoned equity offering. The finding show that under considering shareholdings of insiders, the firm with higher current period's debt agency cost DAgency $_{\text {it }}$ tends to engage in private equity financing in current period, and this result supports Hypothesis H1a.

Overall, both prior and current periods' debt agency costs are positively related to seasoned equity offerings, implying that the firm with higher debt agency cost tends to conduct current period's seasoned equity offerings, our results support Hypothesis H1a.

However, when using EAgency it to measure equity agency cost, we find that current equity agency cost is unrelated to current seasoned equity offerings, so our result do not support Hypothesis $1 b$.

Model 1 of Table 7 shows that the interaction term between current insiders' shareholdings and current debt agency cost is negatively related to current seasoned equity offering financing. This result implies that when higher insiders' shareholdings, the firm with higher debt agency cost does not has higher possibility of engaging in seasoned equity offerings, which supports hypothesis H2a. Moreover, the interaction term between current insiders' shareholdings and current equity agency cost EAgency it $_{\text {is }}$ unrelated to current seasoned equity offering financing, which also does not supports hypothesis $\mathrm{H} 2 \mathrm{~b}$.

On the other hand, in Model 2 of Table 7, the result shows that under considering shareholdings of insiders, the firm with higher current period's debt agency cost DAgency it tends to engage in private equity financing in current period, and this result supports Hypothesis H1c.

Overall, both prior and current periods' debt agency costs are positively related to private equity financing, implying that the firm with higher current debt agency cost tends to conduct private equity financing in current period, our results support Hypothesis H1c.

Model 2 in Table 7 show that under considering shareholdings of insiders, the firm with higher current period's equity agency cost EAgency ${ }_{i t}$ does not tend to engage in private equity financing in current period, and this result supports Hypothesis H1c. The result in Model 2 of Table 7 shows that the interaction term between current insiders' shareholdings and current debt agency cost is unrelated to current private equity financing. Meanwhile, the interaction term between current insiders' shareholdings and current equity agency cost EAgency $y_{i t}$ is also unrelated to current private equity financing. 
Table 7. Insiders' shareholdings, current agency cost and financing choice

\begin{tabular}{|c|c|c|c|c|}
\hline \multicolumn{5}{|c|}{$\begin{aligned} \text { SEODebt }_{i t}= & a_{0}+a_{1} \text { DAgency }_{i t}+a_{2} \text { EAgency }_{i t}+a_{3} \text { InsideS }_{i t}+a_{4} \text { DAgency }_{i t} \text { InsideS }_{i t} \\
& +a_{5} \text { EAgency }_{i t} \text { InsideS }_{i t}+a_{6} \text { AS }_{i t}+a_{7} \text { ROA }_{i t}+e_{i t} \\
\text { PRIDS }_{i t}= & a_{0}+a_{1} \text { DAgency }_{i t}+a_{2} \text { EAgency }_{i t}+a_{3} \text { InsideS }_{i t}+a_{4} \text { DAgency }_{i t} \text { InsideS }_{i t} \\
& +a_{5} \text { EAgency }_{i t} \text { InsideS }_{i t}+a_{6} \text { AS }_{i t}+a_{7} \text { ROA }_{i t}+e_{i t}\end{aligned}$} \\
\hline & \multicolumn{2}{|c|}{$\begin{array}{l}\text { Model } 1 \text { (independent } \\
\text { variable: SEODebt) }\end{array}$} & \multicolumn{2}{|c|}{$\begin{array}{c}\text { Model } 2 \text { (independent variable: } \\
\text { PRIDS) }\end{array}$} \\
\hline variables & Coef. & $\begin{array}{l}\mathrm{z} \text { value } \\
(\mathrm{P}>|\mathrm{z}|)\end{array}$ & Coef. & $\begin{array}{l}z \text { value } \\
\text { ( } p \text { value })\end{array}$ \\
\hline DAgency & 0.4684 & $\begin{array}{c}6.0000 \\
(0.0000)\end{array}$ & 0.2463 & $\begin{array}{l}2.2000 \\
(0.0280)\end{array}$ \\
\hline EAgency & -0.1124 & $\begin{array}{l}-0.7100 \\
(0.4780)\end{array}$ & -0.9971 & $\begin{array}{l}-3.1600 \\
(0.0020)\end{array}$ \\
\hline InsideS & -0.0059 & $\begin{array}{l}-1.9800 \\
(0.0480)\end{array}$ & 0.0132 & $\begin{array}{l}3.1500 \\
(0.0020)\end{array}$ \\
\hline DAgency $_{\text {it }} \times$ Inside $_{\text {it }}$ & -0.0044 & $\begin{array}{l}-3.4000 \\
(0.0010)\end{array}$ & -0.0018 & $\begin{array}{l}-1.0500 \\
(0.2920)\end{array}$ \\
\hline EAgency $_{\text {it }} \times$ InsideS $_{\text {it }}$ & -0.0005 & $\begin{array}{l}-0.1400 \\
(0.8860)\end{array}$ & 0.0100 & $\begin{array}{c}1.5900 \\
(0.1130)\end{array}$ \\
\hline AS & -0.1859 & $\begin{array}{l}-3.1900 \\
(0.0010)\end{array}$ & -0.5360 & $\begin{array}{l}-5.3200 \\
(0.0000)\end{array}$ \\
\hline ROA & -0.0308 & $\begin{array}{l}-6.9700 \\
(0.0010)\end{array}$ & -0.0855 & $\begin{array}{r}-13.0500 \\
(0.0000)\end{array}$ \\
\hline Cons. & -0.5960 & $\begin{array}{l}-1.3600 \\
(0.1750)\end{array}$ & 0.6266 & $\begin{array}{c}0.8500 \\
(0.3970)\end{array}$ \\
\hline $\begin{array}{c}\text { Number of obs. } \\
\text { LR chi2(5) } \\
\text { Prob }>\text { chi2 } \\
\text { Pseudo R2 }\end{array}$ & $\begin{array}{c}5319 \\
169.22 \\
0.0000 \\
0.0317\end{array}$ & & $\begin{array}{c}5319 \\
442.48 \\
0.0000 \\
0.1488\end{array}$ & \\
\hline
\end{tabular}

Variables Definition:

SEODebt is an equity dummy variable, which sets to 1 if the firm chooses seasoned equity offering financing and set to 0 if the firm chooses bank debt, issuing bond, or issuing private equity financings. PRIDS is a private equity dummy variable, which sets to 1 if the firm chooses private equity and set to 0 if the firm chooses bank debt, issuing bond, and seasoned equity offering financings. DAgency is the debt agency cost, which is measured by market to book ratio of equity. EAgency is the equity agency cost, which is measured by the firm's selling and administrative expenses ratio minus the industry median of selling and administrative expenses ratios of all firms in an industry. InsideS is the shareholdings of insiders, which is the sum of managers' shareholdings, directors and supervisors' shareholdings, and blockholders' shareholdings. AS is the nature log of total assets, which controls firm size. ROA is return of assets, which represents the operation performance of a firm.

\section{Conclusions}

This paper examines whether firms tend to choose seasoned equity offering for financing when the debt agency costs of prior and current periods are high, and whether firms tend to choose private equity method for financing when the debt agency cost of prior and current periods are high. Next, we explore whether the shareholdings of insiders would affect the relationship between debt agency cost and seasoned equity offerings, and whether the 
shareholdings of insiders would affect the relationship between equity agency cost and debt financings. We also examine whether the shareholdings of insiders would affect the relationship between agency cost and private equity financing of firms.

The findings show that both prior and current periods' debt agency costs are positively related to seasoned equity offerings, implying that the firm with higher debt agency cost tends to conduct current period's seasoned equity offerings. Next, both prior and current periods' debt agency costs are positively related to private equity financing, implying that the firm with higher current debt agency cost tends to conduct private equity financing in current period. As for equity agency cost, we also find the relationship that both current and prior periods' equity agency costs are negatively related to seasoned equity offerings, implying that the firm with higher equity agency cost tends to conduct debt offerings in current period.

Under considering shareholdings of insiders, the evidences document that both prior and current periods' debt agency costs are positively related to seasoned equity offerings, and both prior and current periods' debt agency costs are positively related to private equity financing, implying that the firm with higher current debt agency cost tends to conduct private equity financing in current period. However, we only find that prior periods' equity agency costs are negatively related to seasoned equity offerings.

However, the interaction term between insiders' shareholdings and prior debt agency cost is unrelated to current seasoned equity offering financing, implying that the insiders' shareholdings would affect the relationship between debt agency cost does and the choice of seasoned equity offering. Moreover, the interaction term between insiders' shareholdings and prior equity agency cost is positively related to current seasoned equity offering financing.

Moreover, the interaction term between insiders' shareholdings and prior debt agency cost is also unrelated to current seasoned equity offering financing, and the interaction term between insiders' shareholdings and prior equity agency cost is unrelated to current seasoned equity offering financing. Moreover, the interaction term between insiders' shareholdings and prior debt agency cost is unrelated to current private equity financing, and the interaction term between insiders' shareholdings and prior equity agency cost is unrelated to current private equity financing. As for private equity financing, the interaction term between prior insiders' shareholdings and prior debt agency cost is unrelated to current private equity, and the interaction term between prior insiders' shareholdings and prior equity agency cost is unrelated to current private equity.

\section{References}

Agrawal, A., \& Knoeber, C. R. (1996). Firm performance and mechanisms to control agency problems between managers and shareholders. Journal of Financial and Quantitative Analysis, 31, 377-397. http://dx.doi.org/10.2307/2331397

Agrawal, A., \& Mandelker, G. (1990). Large shareholders and the monitoring of managers: the case of antitakeover charter amendments. Journal of Financial and Quantitative Analysis, 25, 143-161. http://dx.doi.org/10.2307/2330821

Ahmed, A. S., Billings, B. K., Morton, R. M., \& Stanford-Harris, M. (2002). The role of accounting conservatism in mitigating bondholder-shareholder conflicts over dividend policy and in reducing debt costs. The Accounting Review, 77, 867-890. http://dx.doi.org/10.2308/accr.2002.77.4.867

Alchian, A., \& Demsetz, H. (1972). Production, information costs and economic organization. 
American Economic Review, 62, 777-795.

Ang, J. S., Rebel. A. C., \& James. W. L. (2000). Agency costs and ownership. Journal of Finance, 55, 81-105. http://dx.doi.org/10.1111/0022-1082.00201

Asquith, P., \& Mullins, D. (1986). Equity issues and offering dilution. Journal of Financial Economics, 15, 61-89. http://dx.doi.org/10.1016/0304-405X(86)90050-4

Baker, M., \& Wurgler, J. (2002). Market timing and capital structure. Journal of Finance, 57, 1-32. http://dx.doi.org/10.1111/1540-6261.00414

Berger, P. G., Ofek, E., \& Yermack D. L. (1997). Managerial entrenchment and capital structure decisions. Journal of Finance, 52, 1411-1437. http://dx.doi.org/10.1111/j.1540-6261.1997.tb01115.x

Berle, A., \& Means. G. C. (1932). The modern corporation and private property. New York: Macmillan Publishing Co.

Claessens, S., \& Yurtoglu, B. B. (2013). Corporate governance in emerging markets: a survey. Emerging Markets Review, 15, 1-33. http://dx.doi.org/10.1016/j.ememar.2012.03.002

Colla, P., Ippolito, F., \& Li, K. (2013). Debt specialization. Journal of Finance, 68, 2117-2141. http://dx.doi.org/10.1111/jofi.12052

Cronqvist, H., \& Nilsson, M. (2005). The choice between right offering and private equity

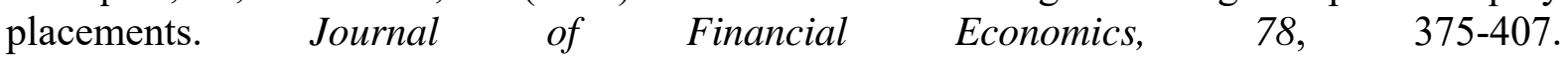
http://dx.doi.org/10.1016/j.jfineco.2004.12.002

Denis D. J., \& McKeon, S. B. (2012). Debt financing and financial flexibility: evidence from proactive leverage increases. The Review of Financial Studies, 25, 1897-1929. http://dx.doi.org/10.1093/rfs/hhs005

Fama, E., \& Jensen, M. (1983). Separation of ownership and control. Journal of Law and Economics, 26, 301-325. http://dx.doi.org/10.1086/467037

Fama. E. F., \& Jensen, M. C. (1983). Agency problems and residual claims. Journal of Law and Economics, 26, 327-349. http://dx.doi.org/10.1086/467038

Frank, M. Z., \& Goyal, V. K. (2003). Testing the pecking order theory of capital structure. $\begin{array}{lllll}\text { Journal of Financial } & \text { Economics, } & 67, & \text { 217-248. }\end{array}$ http://dx.doi.org/10.1016/S0304-405X(02)00252-0

Fuerst, O., \& Kang, S. H. (2000). Corporate governance, expected operation performance, and pricing. Working Paper.

Gamba, A., \& Triantis, A. J. (2008). The value of financial flexibility. Journal of Finance, 63, 2263-2296. http://dx.doi.org/10.1111/j.1540-6261.2008.01397.x

Garleanu, N., \& Zwiebel, J. (2009). Design and renegotiation of debt covenants. The Review of Financial Studies, 22, 749-781. http://dx.doi.org/10.1093/rfs/hhn017

Graham, J., \& Harvey, C. R. (2001). The theory and practice of corporate finance: evidence from the field. Journal of Financial Economics, 60, 187-243. http://dx.doi.org/10.1016/S0304-405X(01)00044-7

Hertzel, M., \& Li, Z. (2010). Behavioral and rational explanations of stock price performance 
around SEOs: evidence from a decomposition of market-to-book ratios. Journal of Financial and Quantitative Analysis, 45, 935-958. http://dx.doi.org/10.1017/S002210901000030X

Hessel, C. A., \& Norman, M. (1992). Financial characteristics of neglected and institutionally hold stocks. Journal of Accounting, Auditing and Financing, 7, 313-330.

Hovakimian, A., Opler, T., \& Titman, S. (2001). The debt-equity choice. Journal of Financial and Quantitative Analysis, 36, 1-24. http://dx.doi.org/10.2307/2676195

Huang, R., \& Ritter, J. R. (2009). Testing theories of capital structure and estimating the speed of adjustment. Journal of Financial and Quantitative Analysis, 44, 237-271. http://dx.doi.org/10.1017/S0022109009090152

Jensen, M. (1986). The agency costs of free cash flows, corporate finance, and takeovers. American Economic Review, 76, 323-329.

Jensen, M. C., \& Mecking, W. H. (1976). Theory of the firm: managerial behavior, agency costs and ownership structure. Journal of Financial Economics, 3, 305-360. http://dx.doi.org/10.1016/0304-405X(76)90026-X

Jensen, M. C., \& Ruback, R. S. (1983). The market for corporate control: the scientific evidence. Journal of Financial Economics, 11, 5-50. http://dx.doi.org/10.1016/0304-405X(83)90004-1

John. K., \& Senbet, L. W. (1998). Corporate governance and board effectiveness. Journal of Banking and Finance, 22, 371-403. http://dx.doi.org/10.1016/S0378-4266(98)00005-3

Kang, F. (2014). Founding family ownership and the selection industry specialist auditors. Accounting Horizon, 28, 261-276. http://dx.doi.org/10.2308/acch-50714

Kim, W., \& Weisbach, M. S. (2008). Motivations for public equity offers: an international perspective. Journal of Financial Economics, 87, 281-307. http://dx.doi.org/10.1016/j.jfineco.2006.09.010

Lee, H., \& Kocher, C. (2001). Firm characteristics and seasoned equity issuance method private placement versus public offering. Journal of Applied Business Research, 17, 23-36.

Leone, A. J., \& Liu, M. (2010). Accounting irregularities and executive turnover in founder-managed firms. The Accounting Review, 85, 287-314. http://dx.doi.org/10.2308/accr.2010.85.1.287

Lins, K. V. (2003). Equity ownership and firm value in emerging markets. Journal of Financial and Quantitative Analysis, 38, 159-184. http://dx.doi.org/10.2307/4126768

Loughran, T., \& Ritter, J. (1997). The operating performance of firms conducting seasoned equity offerings. Journal of Finance, 52, 1823-1850. http://dx.doi.org/10.1111/j.1540-6261.1997.tb02743.x

Malmendier, U., Tate, G., \& Yan, J. (2011). Overconfidence and early-life experiences: the effect of managerial traits on corporate financial policies. Journal of Finance, 66, 1687-1733. http://dx.doi.org/10.1111/j.1540-6261.2011.01685.x

Marchica, M., \& Mura, R. (2010). Financial flexibility, investment ability, and firm value: evidence from firms with spare debt capacity. Financial Management, 39, 1339-1365. http://dx.doi.org/10.1111/j.1755-053X.2010.01115.x 
Marsh, P. (1982). The choice between debt and equity: an empirical study. Journal of Finance, 37, 121-144. http://dx.doi.org/10.1111/j.1540-6261.1982.tb01099.x

Masulis, R., \& Korwar, A. (1986). Seasoned equity offerings: an empirical investigation. Journal of Financial Economics, 15, 91-118. http://dx.doi.org/10.1016/0304-405X(86)90051-6

McKnight, P. J., \& Weir, C. (2009). Agency costs, corporate governance mechanisms and ownership structure in large UK publicly quoted companies: a panel data analysis. Quarterly Review of Economics and Finance, 49, 139-158. http://dx.doi.org/10.1016/j.qref.2007.09.008

McLean, R. (2011). Share issuance and cash savings. Journal of Economics, 99, 693-715.

Morck, R., Shleifer, A., \& Vishny, R. (1988). Management ownership and market valuation: an empirical analysis. Journal of Financial Economics, 20, 293-315. http://dx.doi.org/10.1016/0304-405X(88)90048-7

Myers, S. (1977). Determinants of corporate borrowing. Journal of Financial Economics, 5, 147-175. http://dx.doi.org/10.1016/0304-405X(77)90015-0

Myers, S. C. (1984). The capital structure puzzle. Journal of Finance, 39, 575-592. http://dx.doi.org/10.2307/2327916

Myers, S. C., \& Majluf, N. (1984). Corporate financing and investment decisions when firms have information that investors do not have. Journal of Financial Economics, 13, 187-221. http://dx.doi.org/10.1016/0304-405X(84)90023-0

Rosenstein. S., \& Jeffrey, G. W. (1997). Inside directors, board effectiveness, and shareholder wealth. Journal of Financial Economics, 44, 229-250. http://dx.doi.org/10.1016/S0304-405X(97)00004-4

Singh, M., \& Davidson III, W. N. (2003). Agency costs, ownership structure and corporate governance mechanisms. Journal of Banking and Finance, 27, 793-816. http://dx.doi.org/10.1016/S0378-4266(01)00260-6

Titman, S., \& Wessels, R. (1988). The determinants of capital structure. Journal of Finance 43, 1-19. http://dx.doi.org/10.1111/j.1540-6261.1988.tb02585.x

Wahal, S., \& McConnell, J. J. (2000). Do institutional investors exacerbate managerial Myopia. Journal of Corporate Finance, 6, 307-329. http://dx.doi.org/10.1016/S0929-1199(00)00005-5

Walsh, J. P., \& Seward, J. K. (1990). On the efficiency of internal and external corporate control mechanisms. Academy of Management Review, 15, 421-458.

Li, X., Tuna, A. I., \& Vasvari, F. P. (2013). Corporate governance and restrictions in debt contracts. Working Paper.

Zantout, Z. (1994). External capital market control, corporate restructuring, and firm performance during the 1980s. Journal of Business Finance and Accounting, 21, 37-64. http://dx.doi.org/10.1111/j.1468-5957.1994.tb00304.x 